\title{
Keragaan Vegetatif dan Generatif Beberapa Varietas Tanaman Padi (Oryza sativa L.) Terhadap Cekaman Kekeringan pada Fase Pertumbuhan yang Berbeda
}

DOI 10.18196/pt.2014.019.20-27

\author{
Hariyono \\ Program Studi Agroteknologi, Fakultas Pertanian, Universitas Muhammadiyah Yogyakarta, \\ Jl. Lingkar Selatan,Kasihan, Bantul, Yogyakarta 55183; e-mail:hary@fp.umy.ac.id
}

\begin{abstract}
ABSTRAK
Penelitian ini bertujuan untuk mempelajari keragaan vegatatif dan generatif beberapa varietas tanaman padi terhadap cekaman keringan pada fase pertumbuhan yang berbeda. Penelitian ini dilaksanakan di lahan Fakultas Pertanian, Universitas Muhammadiyah Yogyakarta, Kasihan Bantul, dari bulan Maret hingga Bulan Juni 2010. Penelitian dilaksanakan dengan metode percobaan lapangan faktorial 4 × 5 yang disusun dalam Rancangan Acak Lengkap dengan tiga ulangan. Faktor pertama yaitu varietas padi terdiri dari IR 64, Menthik, Cisadane dan Dodokan. Faktor kedua yaitu saat cekaman kekeringan terdiri atas lima aras yaitu periode vegetatif, periode bunting, periode pembungaan dan periode pengisian biji serta tanpa cekaman kekeringan sebagai kontrol. Hasil Penelitian menunjukkan bahwa varietas Cisadane lebih tahan terhadap cekaman kekeringan bila dibandingkan dengan varietas lainnya, selain itu kekeringan pada fase vegetatif mengalami penurunan jumlah biji per rumpun bila dibandingkan dengan kekeringan pada fase pertumbuhan lainnya.

Kata kunci : Padi, Cekaman Kekeringan
\end{abstract}

\begin{abstract}
The research was conducted to study the effects of drought stress conditions on the performance of vegetative and generative of various rice varieties on the different growth stages. The research was performed at field trial of Faculty of Agriculture, Muhammadiyah University of Yogyakarta, Kasihan Bantul, from March to June 2010. The research was designed using a factorial experiment that arranged in Completely Randomized Design $4 \times 5$ with three replications. The first factor was the varieties of rice i.e. IR 64, Menthik, Cisadane and Dodokan. The second factor was the period of drought stress at the difference plant stage, i.e at the vegetative period, booting period, heading period, grain filling period, and without drought stress or control. The results showed that Cisadane varieties had a higher tolerance to the drought stress than to all varieties. Moreover, the plant treated on drought stress at vegetative period had lower grain number per hill than the other drought stress period.

Key words: rice, drought stress
\end{abstract}

\section{PENDAHULUAN}

Pangan merupakan kebutuhan pokok terpenting bagi kehidupan manusia, setelah udara dan air. Tanpa pangan manusia tidak dapat hidup, bahkan tanpa pangan yang baik, manusia tidak dapat hidup layak. Oleh karenanya pemenuhan kebutuhan pangan merupakan hak azasi untuk setiap manusia yang harus dihormati dan mendapat kesempatan untuk diwujudkan.Padi (Oriza sativa) merupakan sumber bahan utama bagi sepertiga penduduk dunia,terutama Asia karena 90\% beras diproduksi dan dikonsumsi di Asia. Di Indonesia padi telah menjadi sumber kehidupan sejak ribuan tahun lalu dan sekarang lebih dari 90\% penduduk Indonesia yang lebih dari 200 juta mengkonsumsi beras sebagai bahan makanan pokok (Abdullah, 2002).

Beras merupakan makanan pokok bagi penduduk Indonesia. Oleh sebab itu situasi beras secara tidak langsung dapat 
mempengaruhi situasi bahan-bahan konsumsi lainnya(Soemartono, 1979). Kegagalan untuk memenuhi kebutuhan masyarakat akan bahan makanan pokok dapat menggoyahkan ekonomi dan ketahanan nasional.

Tanaman padi menghendaki tempat serta lingkungan tumbuh yang terbuka, banyak mendapatkan sinar matahari. Beberapa tipe budidaya padi yang dilaksanakan di Indonesia adalah : padi sawah, padi pasang surut, padi lebak, padi gogo dan gogo rancah, yang semua itu didasarkan atas habitatnya.Tanaman padi di daerah lahan kering yang biasa disebut dengan padi gogo meruakan padi yang ditanam dan dipelihara secara kering di atas lahan yang diolah secara kering, dan tidak memerlukan pematang penahan air, karena kebutuhan airnya didapat dari air hujan.Pengembangan varietas unggul diarahkan untuk mendapatkan sifat-sifat potensi hasil tinggi, tahan/toleran tehadap cekaman abiotik dan biotik, mutu hasil yang tinggi, sesuai dengan selera konsumen dan pasar.

Kekeringan merupakan salah satu kendala utama produksi padi lahan sawah atau tadah hujan (Mackill et.al., 1996 cit Suardi,2000) selain itu juga berpengaruh terhadap stabilitas hasil (Babu et.al,1996 cit Suardi, 2000). Diperkirakan kehilangan hasil akibat cekaman lingkungan dan hama penyakit lebih dari 200 juta ton padi pertahun (Herdt,1991; Chen and Murata, 2002 cit Pirdashti et.al.,2004). Menurut data Badan Pusat Statistik (2013), di Indonesia pada tahun 2002, luas daerah sentra tanaman padi yang mengalami cekaman kekeringan mencapai 236 ribu ha (tidak termasuk papua). Dari total luas tersebut 38.900 ha areal pertanaman padi puso (tidak dapat dipanen) akibat cekaman kekeringan.

Cekaman kekeringan dapat terjadi di berbagai periode pertumbuhan tanaman padi, dapat terjadi pada periode vegetatif, periode pembungan, dan periode pematangan biji. Lama dan intensitasnya bervariasi mempengaruhi pertumbuhan dan hasil. Hasil penelitian empat kultivar padi menunjukkan kekurangan air pada saat periode vegetetatif, periode pembungaan,dan pemasakan biji menurunkan hasil rata-rata 21\%,50\%, dan 21\% dari pada kontrolnya. Pembungaan dapat tertunda sekitar 2-5 minggu karena cekaman kekeringan, pada beberapa kasus bunga sering tidak muncul. Kehilangan hasil akibat cekaman kekeringan dapat mencapai 50\% dari total hasil, bergantung periode terjadinya cekaman kekeringan (Pirdashti, et. al.,2004).

Tingkat hasil suatu tanaman selain dipengaruhi oleh keadaan lingkungan disekelilinginya juga di pengaruhi oleh sifat genetis tanaman. Sifat genetis tanaman merupakan sifat bawaan yang diturunkan oleh induknya dan setiap varietas tanaman mempunyai sendiri untuk menggambarkan sifat genetisnya disamping itu tidak semua varietas unggul memunculkan sifat-sifat unggul yang di harapkan. Salah satu cara untuk mengurangi kerugian karena kekeringan adalah menggunakan varietas padi yang tahan atau toleran terhadap kekeringan.

\section{BAHAN DAN METODE}

\section{Penelitian telah dilakukan di lahan} percobaan fakultas pertanian Universitas Muhammadiyah Yogyakarta, Tamantirto, Kasihan, Bantul, Yogyakarta, dengan jenis tanah regosol. Penelitian dilaksanakan pada bulan Maret sampai Juni tahun 2010.

Bahan yang digunakan adalah benih varietas IR 64, Menthik, Cisadane dan Dodokan. Pupuk kandang kambing, pupuk Urea, KCl, SP-36, 
pestisida Furdan dan Regent. Alat yang digunakan: ember, cetok, polybag $40 \mathrm{~cm}$ x 40 $\mathrm{cm}$, timbangan elektrik, penggaris, oven, pengukur LAI, alat tulis.

Penelitian dilaksanakan dengan metode percobaan lapangan faktorial 4 x 5 yang disusun dalam Rancangan Acak Lengkap. Faktor pertama yaitu varietas padi terdiri atas empat jenis yaitu IR 64, Menthik, Cisadane dan Dodokan. Faktor kedua yaitu saat cekaman kekeringan terdiri atas lima aras yaitu periode vegetatif, periode bunting, periode pembungaan dan periode pengisian biji serta tanpa cekaman kekeringan sebagai kontrol, sehingga diperoleh 20 kombinasi perlakuan. Tiap kombinasi perlakuan terdiri atas 6 polybag dan masingmasing kombinasi perlakuan diulang tiga kali.

Variabel pengamatan meliputi tinggi tanaman $(\mathrm{cm})$, jumlah anakan per rumpun, jumlah daun (helai), luas daun (cm), umur berbunga (hari), berat kering tajuk (g), berat kering akar $(\mathrm{g})$, volume akar (ml), panjang akar (cm), Nisbah Tajuk/ Akar, jumlah malai per rumpun, jumlah biji per malai, Gejala kekeringan, dilakukan setelah perlakuan cekanam perlakuan diaplikasikan, diamati berdasarkan Standart Evaluation For Rice (IRRI,1996) sebagai berikut; $1=$ Tidak ada atau sedikit sekali pengaruh cekaman kekeringan; $3=$ Ujung daun sedikit mengering dan memanjang sampai $1 / 4$ panjang daun dari tanaman; 5 = daun mengering dari $1 / 4$ sampai $1 / 2$ panjang daun seluruh daun tanaman; $7=\mathrm{T}$ ! dari seluruh jumlah daun sampai seluruh daun mengering; 9 = Seluruh daun mati.

Data yang terkumpul dianalisis menggunakan Analisis varian pada jenjang $5 \%$. Apabila hasil analisis menunjukkan beda nyata, maka dilakukan uji DMRT (Duncan Multiple Range
Test) pada jenjang $5 \%$ untuk mengetahui kombinasi mana yang berbeda.

\section{HASIL DAN PEMBAHASAN}

Rerata tinggi tanaman menunjukkan bahwa tinggi tanaman varietas Dodokan lebih tinggi dibandingkan ketiga varietas lainnya. Hal ini karena secara genetik varietas Dodokan mempunyai bentuk tanaman yang lebih tinggi dan lebih besar dibandingkan ketiga varietas lainnya, juga mempunyai bentuk perakaran yang panjang dan dalam sehingga lebih eksplore dalam mendapatkan air dan unsur hara, jadi kekeringan yang terjadi selama dua minggu belum mampu menghambat pertumbuhannya

Tabel 1. Rerata Tinggi Tanaman, Jumlah Anakan, Jumlah Daun, Luas Daun Umur 6 Minggu Setelah Tanam dan Berat Kering Tajuk Saat Panen

\begin{tabular}{lllll}
\hline PERLAKUAN & $\begin{array}{l}\text { Tinggi } \\
\text { Tanaman }(\mathrm{cm})\end{array}$ & $\begin{array}{l}\text { Jumlah } \\
\text { Anakan }\end{array}$ & $\begin{array}{l}\text { Jumlah } \\
\text { daun }\end{array}$ & $\begin{array}{l}\text { Luas daun } \\
\left(\mathrm{cm}^{2}\right)\end{array}$ \\
\hline $\begin{array}{l}\text { Varietas } \\
\text { IR 64 }\end{array}$ & $83,13 \mathrm{~b}$ & $27,05 \mathrm{~b}$ & $75,67 \mathrm{a}$ & $122,81 \mathrm{a}$ \\
Menthik & $81,80 \mathrm{~b}$ & $21,23 \mathrm{a}$ & $78,51 \mathrm{a}$ & $121,96 \mathrm{a}$ \\
Cisadane & $86,57 \mathrm{~b}$ & $25,39 \mathrm{ab}$ & $76,82 \mathrm{a}$ & $124,45 \mathrm{a}$ \\
Dodokan & $114,44 \mathrm{a}$ & $17,80 \mathrm{~b}$ & $46,37 \mathrm{~b}$ & $94,49 \mathrm{~b}$ \\
Cekaman Kekeringan & & & & \\
Tanpa Cekaman & $83,35 \mathrm{p}$ & $23,87 \mathrm{p}$ & $73,38 \mathrm{p}$ & $140,36 \mathrm{p}$ \\
Periode Vegetatif & $80,10 \mathrm{p}$ & $16,51 \mathrm{r}$ & $63,69 \mathrm{~s}$ & $90,90 \mathrm{~s}$ \\
Periode Bunting & $79,56 \mathrm{p}$ & $19,36 \mathrm{q}$ & $70,78 \mathrm{q}$ & $100,42 \mathrm{q}$ \\
Periode Pembungaan & $79,27 \mathrm{p}$ & $19,57 \mathrm{q}$ & $67,24 \mathrm{r}$ & $95,78 \mathrm{r}$ \\
Periode Pengisian Biii & $80,79 \mathrm{p}$ & $19,34 \mathrm{q}$ & $67,43 \mathrm{r}$ & $94,85 \mathrm{r}$ \\
Interaksi & $(?)$ & $(?)$ & $(?)$ & $(?)$ \\
\hline
\end{tabular}

Keterangan: Angka yang diikuti huruf yang sama pada kolom yang sama tidak ada beda nyata berdasarkan uji DMRT pada taraf $5 \%$.

Pada tabel 1 menunjukkan Varietas IR 64, Cisadane dan Menthik menghasilkan anakan lebih banyak dibandingkan Dodokan karena secara genetik Dodokan anakannya memang 
Tabel 2. Rata-Rata Berat Kering Tajuk, Berat Kering Akar pada Umur 6 Minggu (g), Panjang Akar Umur 6 Minggu (cm) dan Rasio Tajuk Akar Umur 6 Minggu, Berat Kering Akar Saat Panen (g).

\begin{tabular}{llcccc}
\hline VARIETAS & CEKAMAN & $\begin{array}{c}\text { BERAT KERING } \\
\text { TAJUK6MG }\end{array}$ & $\begin{array}{c}\text { BERAT KERING } \\
\text { AKAR 6MG }\end{array}$ & $\begin{array}{c}\text { BERAT KERING } \\
\text { AKAR PANEN }\end{array}$ & $\begin{array}{c}\text { PANJANG AKAR } \\
6 M G\end{array}$ \\
\hline IR 64 & Fase Vegetatif & $13.80 \mathrm{c}$ & $10.65 \mathrm{fgh}$ & $28.40 \mathrm{cdefg}$ & $34.50 \mathrm{ef}$ \\
& Fase Bunting & $14.36 \mathrm{bc}$ & $13.61 \mathrm{efgh}$ & $36.12 \mathrm{bc}$ & $53050 \mathrm{bcd}$ \\
& Fase Flowering & $14.25 \mathrm{a}$ & $27.25 \mathrm{abcd}$ & $32.00 \mathrm{bcde}$ & $57.33 \mathrm{~b}$ \\
& Fase Pengisian biij & $11.37 \mathrm{~b}$ & $32.02 \mathrm{a}$ & $32.39 \mathrm{bcde}$ & $48.83 \mathrm{bcde}$ \\
& Tanpa Perlakuan & $17.85 \mathrm{de}$ & $17.49 \mathrm{cdef}$ & $42.86 \mathrm{ab}$ & $50.73 \mathrm{bcd}$ \\
Menthik & Fase Vegetatif & $14.57 \mathrm{~d}$ & $11.68 \mathrm{efgh}$ & $29.41 \mathrm{cdefg}$ & $32.00 \mathrm{f}$ \\
& Fase Bunting & $16.75 \mathrm{~d}$ & $28.35 \mathrm{abc}$ & $32.43 \mathrm{bcde}$ & $40.33 \mathrm{def}$ \\
& Fase Flowering & $16.59 \mathrm{~d}$ & $33.86 \mathrm{a}$ & $38.65 \mathrm{abc}$ & $44.67 \mathrm{cdef}$ \\
& Fase Pengisian biij & $12.15 \mathrm{bc}$ & $20.16 \mathrm{cdef}$ & $30.78 \mathrm{bcdef}$ & $46.50 \mathrm{bcde}$ \\
& Tanpa Perlakuan & $20.64 \mathrm{e}$ & $16.05 \mathrm{efgh}$ & $22.01 \mathrm{defgh}$ & $39.83 \mathrm{def}$ \\
& Fase Vegetatif & $12.49 \mathrm{cde}$ & $13.27 \mathrm{efgh}$ & $17.20 \mathrm{fgh}$ & $47.33 \mathrm{bcde}$ \\
& Fase Bunting & $13.60 \mathrm{c}$ & $33.79 \mathrm{a}$ & $32.55 \mathrm{bcd}$ & $43.00 \mathrm{cdef}$ \\
& Fase Flowering & $13.98 \mathrm{~b}$ & $21.05 \mathrm{bcde}$ & $35.97 \mathrm{bc}$ & $49.50 \mathrm{bcd}$ \\
& Fase Pengisian biij & $11.40 \mathrm{~b}$ & $31.19 \mathrm{a}$ & $33.49 \mathrm{bcd}$ & $53.67 \mathrm{bc}$ \\
& Tanpa Perlakuan & $16.67 \mathrm{~d}$ & $16.95 \mathrm{defg}$ & $49.84 \mathrm{a}$ & $50.00 \mathrm{bcd}$ \\
& Fase Vegetatif & $10.23 \mathrm{a}$ & $12.14 \mathrm{efgh}$ & $13.76 \mathrm{~g}$ & $41.33 \mathrm{def}$ \\
& Fase Bunting & $11.87 \mathrm{~b}$ & $6.87 \mathrm{gh}$ & $18.38 \mathrm{efgh}$ & $44.00 \mathrm{cdef}$ \\
& Fase Flowering & $11.87 \mathrm{~b}$ & $6.89 \mathrm{fgh}$ & $22.13 \mathrm{defgh}$ & $54.90 \mathrm{bc}$ \\
& Fase Pengisian biii & $9.76 \mathrm{a}$ & $7.17 \mathrm{~h}$ & $20.72 \mathrm{defgh}$ & $76.50 \mathrm{a}$ \\
& Tanpa Perlakuan & $15.89 \mathrm{~d}$ & $10.84 \mathrm{fgh}$ & $15.23 \mathrm{fg}$ & $47.53 \mathrm{bcde}$ \\
\hline & & & &
\end{tabular}

Keterangan: Angka yang diikuti huruf yang sama pada kolom yang sama tidak ada beda nyata berdasarkan uji DMRT pada taraf $5 \%$.

sedikit. Dodokan mempunyai penampang luas daun yang lebih lebar dibandingkan varietas lainnya tetapi karena jumlah anakannya sedikit maka jumlah daun dan luas daunnya pun kecil. Varietas Menthik meskipun memiliki jumlah anakan dan jumlah daun lebih banyak tetapi karena secara genetik tanaman ini lebih pendek, bentuk daun lebih kecil dan penampang daunnya pun sempit menyebabkan luas daunnya pun lebih kecil dibandingkan Varietas IR 64 dan Cisadane.

Perlakuan cekaman berpengaruh nyata terhadap jumlah anakan yang tebentuk.

Kekeringan selama dua minggu mempengaruhi produksi anakan. Pada fase vegetatif jumlah anakan yang terbentuk lebih banyak dibandingkan kontrol. Hal ini menunjukkan pengairan tergenang menghambat pertumbuhan anakan, dimana kondisi kelebihan air, oksigen tidak dapat di serap oleh akar pada zone perakaran sehingga metabolisme tanaman menjadi terganggu. Jumlah anakan pada tanaman yang diairi (tanpa perlakuan / kontrol) mempunyai anakan lebih sedikit 
dibandingkan dengan perlakuan cekaman (fase vegetatif) sehingga jumlah daunpun lebih sedikit

Pada perlakuan cekaman saat fase vegetatif mempunyai luas lebih sempit daripada luas daun tanpa perlakuan, menyempitnya luas daun merupakan respon tanaman terhadap cekaman kekeringan yang diberikan. Daun tanaman akan menggulung dan menyempit untuk mengurangi hilangnya air dari dalam organ tanaman karena terjadinya transpirasi.

Sedangkan pada saat panen varietas berpengaruh nyata dan cekaman kekeringan belum memberi pengaruh yang nyata terhadap berat kering tajuk, hal ini karena varietas mampu melakukan rekoveri terhadap cekaman yang terjadi selama fase pertumbuhannya, sehingga saat panen, faktor genotipelah yang mempengaruhi pertumbuhan berat tajuk.

Saat panen, varietas IR 64 dan varietas Cisadane mempunyai nilai berat kering tajuk yang hampir sama., tetapi nilai berat kering tajuk terendah adalah Dodokan disebabkan karena serangan hama tersebut. Secara umum cekaman kekeringan yang terjadi pada fase vegetatif dan pembungaan menghasilkan berat kering yang paling kecil dibandingkan dengan perlakuan cekaman lainnya.

Pada tabel nilai berat kering tajuk vegetatif kerkecil dimiliki varietas IR 64 dan nilai terbesar pada varietas Menthik. Rendahnya berat kering tajuk pada varietas IR 64 disebabkan varietas ini merupakan padi sawah artinya IR 64 ini belum mampu beradaptasi pada lingkungan kurang air. Sedangkan rendahnya nilai tajuk kering pada Dodokan disebabkan varietas ini banyak terserang hama pada saat fase vegetatif.

Pada tabel 2 secara umum menunjukkan cekaman stress yang di perlakukan pada fase pertumbuhan vegetatif menghambat pertumbuhan akar tanaman varietas IR 64 karena varietas ini mempunyai nilai kering akar yang lebih kecil di bandingkan varietas lainnya. Hal ini berarti secara genetik varietas IR 64 kurang dapat beradaptasi dengan kondisi kekeringan yang ada, di bandingkan varietas Menthik dan Dodokan.

Pada umur enam minggu varietas Dodokan memiliki akar yang paling panjang daripada varietas yang lainnya. Secara umum semua varietas memiliki panjang akar pada cekaman fase vegetatif yang lebih kecil daripada tanaman tanpa perlakuan. Hal ini menunjukkan bahwa cekaman kekeringan menghambat pertumbuhan akar. Pada fase vegetatif (umur 6 minggu), secara umum rasio tajuk dan akar pada tanaman bervariasi antar perlakuan cekaman dan antar varietas. Dodokan memiliki rasio tajuk dan akar paling tinggi, Cisadane paling rendah. Hal ini karena Dodokan tahan terhadap kondisi kekeringan sedang Cisadane kurang adaptif terhadap kekeringan.

Tabel 3. Rata-rata Panjang Akar Panen (cm), Volume Akar Umur 6 Minggu (ml), Volume Akar Saat Panen (ml), Rasio Tajuk Akar Panen.

\begin{tabular}{|c|c|c|c|c|}
\hline PERLAKUAN & $\begin{array}{l}\text { PANJANG } \\
\text { AKAR PANEN }\end{array}$ & $\begin{array}{l}\text { VOLUME AKAR } \\
6 \text { MG }\end{array}$ & $\begin{array}{l}\text { VOLUME AKAR } \\
\text { SAAT PANEN }\end{array}$ & $\begin{array}{l}\text { RASIO TAJUK } \\
\text { AKAR PANEN }\end{array}$ \\
\hline \multicolumn{5}{|l|}{ Varietas } \\
\hline IIR 64 & $38.97 \mathrm{~b}$ & 94.26 a & $93.67 \quad a$ & $1.67 b$ \\
\hline Menthik & $35.47 \mathrm{~b}$ & $106.00 \mathrm{a}$ & $80.14 b$ & $1.53 \mathrm{~b}$ \\
\hline Cisadane & $37.92 b$ & $106.00 a$ & $91.68 \quad a$ & $1.81 \mathrm{~b}$ \\
\hline Dodokan & 43.99 a & 73.33 a & $68.49 \mathrm{c}$ & $2.62 a$ \\
\hline \multicolumn{5}{|l|}{ Cekaman Kekeringan } \\
\hline Tanpa cekaman & $39.05 p$ & $98,67 p$ & $78.70 \mathrm{qr}$ & $1.86 q$ \\
\hline Periode Vegetatif & $36.12 p$ & $99,17 p$ & $73.44 r$ & $2.35 p$ \\
\hline Periode Bunting & $39,50 p$ & $92,83 p$ & $83.89 \mathrm{pqr}$ & $1.85 \mathrm{qr}$ \\
\hline Periode Flowering & $39,30 p$ & $101,67 p$ & $87.83 \mathrm{pq}$ & $1.57 \mathrm{~s}$ \\
\hline Periode Pengisian Biii & $40,34 p$ & $81,67 p$ & $9.229 p$ & $1.75 r$ \\
\hline
\end{tabular}

Keterangan: Angka yang diikuti huruf yang sama pada kolom yang sama tidak ada beda nyata berdasarkan uji DMRT pada taraf $5 \%$. 
Pada tabel 3 terlihat panjang akar saat panen berbeda-beda antar varietas. Varietas Dodokan memiliki akar yang lebih panjang daripada varietas yang diuji lainnya. Sedangkan panjang akar antar perlakuan cekaman kekeringan tidak berbeda nyata. Hal ini diduga karena ruang untuk tumbuh akar pada percobaan tersebut terbatas, mengingat percobaan dilakukan pada polybag di rumah plastik (sungkup). Akar tidak mendapat kesempatan untuk tumbuh memanjang sebagai respon akar terhadap ketersediaan lengas tanah yang terbatas untuk tanaman yang toleran terhadap cekaman kekeringan. Perlakuan cekaman pada fase vegetatif mempunyai panjang akar lebih pendek di bandingkan perlakuan lainnya. Hal tersebut menunjukkan bahwa cekaman kekeringan yang terjadi berpengaruh terhadap pertumbuhan akar.

Tabel menunjukkan saat umur 6 minggu varietas Dodokan mempunyai nilai volume akar paling kecil, hal ini karena adanya serangan hama pada tanaman yang dijadikan sampel tersebut. Saat panen volume akar antar varietas ada beda nyata. Varietas IR 64 memiliki volume akar yang besar disusul oleh varietas Menthik sedangkan Dodokant mempunyai volume akar terkecil. Rata-rata volume akar saat panen pada cekaman fase vegetatif lebih kecil daripada tanpa cekaman yang menunjukkan adanya hambatan pertumbuhan akar karena cekaman kekeringan selama fase vegetatif.

Pada fase generatif rasio tajuk akar Dodokan mempunyai nilai tertinggi sedangkan varietas Menthik paling rendah. Hal ini berarti secara genetik Dodokan tahan cekaman kekeringan, dengan adanya air jumlah klorofil dalam daun menjadi lebih banyak sehingga proses fotosintesis daun jadi aktif, translokasi hasil perlakuan cekaman, rasio tajuk dan akar tertinggi saat cekaman fase vegetatif dan terendah pada saat flowering. Kekurangan air yang menghambat pertumbuhan ujung dan akar,mempunyai pengaruh yang lebih besar terhadap pertumbuhan ujung (Loomis,1953 at Gardner,1991).

Tabel 4. Rata-rata Umur Berbunga (HST)

\begin{tabular}{lll}
\hline VARIETAS & CEKAMAN & $\begin{array}{l}\text { UMUR } \\
\text { BERBUNGA }\end{array}$ \\
\hline IR 64 & Periode Vegetatif & $73.53 \mathrm{a}$ \\
& Periode Bunting & $67.00 \mathrm{bc}$ \\
& Periode Flowering & $63.33 \mathrm{~cd}$ \\
& Periode Pengisian biii & $63.33 \mathrm{~cd}$ \\
& Tanpa Perlakuan & $65.60 \mathrm{bc}$ \\
Menthik & Periode Vegetatif & $59.00 \mathrm{de}$ \\
& Periode Bunting & $58.87 \mathrm{de}$ \\
& Periode Flowering & $54.67 \mathrm{ef}$ \\
& Periode Pengisian biii & $54.00 \mathrm{f}$ \\
& Tanpa Perlakuan & $55.67 \mathrm{ef}$ \\
Cisadane & Periode Vegetatif & $67.07 \mathrm{bc}$ \\
& Periode Bunting & $68.93 \mathrm{ab}$ \\
& Periode Flowering & $63.87 \mathrm{c}$ \\
& Periode Pengisian biji & $67.53 \mathrm{bc}$ \\
& Tanpa Perlakuan & $66.40 \mathrm{bc}$ \\
Dodokan & Periode Vegetatif & $40.00 \mathrm{~g}$ \\
& Bunting & $36.80 \mathrm{~g}$ \\
& Periode Flowering & $37.47 \mathrm{~g}$ \\
& Periode Pengisian biii & $39.47 \mathrm{~g}$ \\
& Tanpa Perlakuan & $35.73 \mathrm{~g}$ \\
\hline
\end{tabular}

Keterangan:Angka yang diikuti huruf yang sama pada kolom yang sama tidak ada bedanyata berdasarkan uji DMRT pada taraf $5 \%$

Tabel 4 menunjukkan bahwa varietas, fase terjadinya kekeringan, dan kekeringan berpengaruh nyata terhadap umur berbunga. Tanaman mempunyai umur berbunga yang berbeda antar varietas. Dodokan berumur paling genjah, disusul varietas Menthik, 
sedangkan Cisadane dan IR 64 yang memiliki umur berbunga sama ketika tidak diperlakukan cekaman.Perlakuan cekaman kekeringan terutama pada fase pertumbuhan (vegetatif) dan bunting memperlambat umur berbunga tanaman pada semua varietas yang diuji. Cekaman kekeringan yang terjadi pada fase vegetatif sangat berpengaruh terhadap lambatnya umur berbunga tanaman pada varietas Cisadane dan IR 64. Pada varietas Menthik bunga lebih cepat terjadi saat fase pengisian biji karena pada fase ini air tidak banyak dibutuhkan dan saat perlakuan kelembaban tinggi sehingga tidak terjadi proses evapotranpirasi yang cukup tinggi. Pada varietas Dodokan cekaman stadia pengisian biji mempunyai umur berbunga yaitu 39 hari setelah tanam,hal ini terjadi meskipun pada stadia ini air tidak banyak dibutuhkan tetapi karena ada tanaman yang banyak terserang hama sehingga proses metabolismenya menjadi terganggu dan bunga muncul lebih lama.

Tabel 5. Rata-rata Jumlah Malai dan Jumlah Biji Perumpun

\begin{tabular}{lll}
\hline PERLAKUAN & $\begin{array}{l}\text { JUMLAH MALAI } \\
\text { PER RUMPUN }\end{array}$ & $\begin{array}{l}\text { JUMLAH BIJI } \\
\text { PER RUMPUN }\end{array}$ \\
\hline Varietas & & \\
IR 64 & $13.21 \mathrm{~b}$ & $603,04 \mathrm{~b}$ \\
Menthik & $16.56 \mathrm{a}$ & $580,48 \mathrm{~b}$ \\
Cisadane & $16.77 \mathrm{a}$ & $769,28 \mathrm{a}$ \\
Dodokan & $7.84 \mathrm{c}$ & $430,90 \mathrm{c}$ \\
& & \\
Cekaman Kekeringann & & \\
tanpa cekaman & $12.32 \mathrm{p}$ & $573,24 \mathrm{pq}$ \\
Periode vegetatif & $13.57 \mathrm{p}$ & $475,80 \mathrm{r}$ \\
Periode bunting & $14.72 \mathrm{p}$ & $607,37 \mathrm{pq}$ \\
Periode pembungaan & $14.03 \mathrm{p}$ & $662,02 \mathrm{p}$ \\
periode pengisian Biii & $13.35 \mathrm{p}$ & $661,20 \mathrm{p}$ \\
Interaksi & $(-)$ & $(-)$ \\
\hline
\end{tabular}

Keterangan:Angka yang diikuti huruf yang sama pada kolom yang sama tidak ada bedanyata berdasarkan uji DMRT pada taraf $5 \%$
Tabel 5 menunjukkan rata-rata jumlah malai terendah adalah varietas IR 64, karena secara genetik varietas ini tidak tahan dengan kondisi kekurangan air, dimana kurangnya air mengurangi jumlah anakan yang dihasilkan,tetapi kelebihan air pada varietas IR 64 juga menyebabkan anakan yang dihasilkan menjadi rendah. Tetapi secara umum kelebihan air menyebabkan produksi malai yang rendah pada kontrol di bandingkan perlakuan cekaman kekeringan.

Tabel 7. Skore Toleransi Kekeringan Empat Varietas Padi pada Fase Cekaman yang Berbeda.

\begin{tabular}{lcccc}
\hline \multirow{2}{*}{ CEKAMAN } & \multicolumn{4}{c}{ VARIETAS } \\
\cline { 2 - 5 } & IR 64 & Menthik & Cisadane & Dodokan \\
\hline Kontrol & 1 & 1 & 1 & 1 \\
PeriodeVegetatif & 3 & 3 & 3 & 3 \\
Periode Bunting & 5 & 3 & 5 & 1 \\
PeriodeBerbunga & 5 & 5 & 5 & 1 \\
PeriodePengisian Biii & 5 & 3 & 5 & 1 \\
\hline
\end{tabular}

\footnotetext{
Keterangan:

$1=$ Tidakadaatau sedikitsekali pengaruhcekamankekeringan;

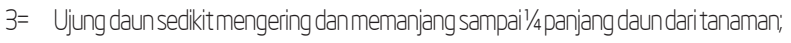

$5=$ daunmengering dari $1 \frac{1}{4}$ sampapanjang daunseluruh daun tanaman;

$7=$ T! dariseluruhjumlah daun sampai seluruh daunmengering;

$9=$ Seluruhdaunmati.
}

Pada tabel 6 terlihat Dodokan mempunyai jumlah biji terendah, sedangkan Cisadane mempunyai nilai jumlah biji tertinggi. Varietas IR 64 meskipun jumlah malainya lebih sedikit tetapi hasil bijinya cukup tinggi yang tidak terlalu bervariasi dengan Menthik. Hal ini menunjukkan jumlah malai yang sedikit tidak mempengaruhi produksi biji perumpun, karena jumlah malai perumpun ditentukan pertumbuhan periode vegetatif sedangkan jumlah biji dalam satu malai sangat tergantung pada kegiatan tanaman selama periode 
reproduksi. Perlakuan pembungaan dan pengisian biji mempunyai jumlah biji perumpun lebih besar dibandingkan periode vegetatif.

Kegiatan fotosintesis selama periode ini mempengaruhi jumlah gabah per malai. Faktor genetik juga mempengaruhi hasil biji, dimana Menthik secara genetik sebagai varietas lokal potensi hasilnya cenderung lebih rendah dibandingkan IR 64. Pada periode pembungaan dan pengisian biji cekaman kekeringan cenderung tidak mempengaruhi kegiatan fotosintesis tanaman sehingga biji yang dihasilkan lebih tinggi.

Pada tabel 7 menunjukkan Varietas Dodokan merupakan varietas yang paling toleran terhadap cekaman air selama dua minggu dibandingkan varietas lainnya. Varietas ini mampu mempertahankan daun tetap hijau yang waktunya lebih lama dibandingkan varietas lainnya. Hal ini karena secara genetik Dodokan selain mempunyai akar yang panjang, dalam, padat, daya tembus (penetrasi) akarnya tinggi. Sedangkan varietas IR 64, Cisadane dan Menthik dalam beradaptasi terhadap kondisi kekeringan menggulungkan daun-daunnya untuk menghindari transpirasi yang lebih tinggi, terutama pada fase vegetatif dan bunting, karena pada waktu itu cuaca sangat panas dengan kelembaban yang rendah dan meskipun tanaman dapat segar kembali warna daun tetap kuning tidak bisa kembali hijau.

Cekaman kekeringan pada saat pembungaan merupakan periode yang sangat sensistif terhadap pembentukan biji. Nilai skore cekaman kekeringan pada fase berbunga menunjukkan bahwa varietas memiliki respon yang berbeda terhadap cekaman kekeringan pada fase tersebut. Pada fase berbunga, skore varietas Dodokan adalah 1 yang menunjukkan varietas ini sangat toleran. Varietas Menthik agak toleran, sedangkan varietas IR 64 dan Cisadane memiliki respon agak peka terhadap stress air. Pada fase pengisian biji varietas yang mendapat cekaman kekeringan memiliki respon agak toleran (5) yang menunjukkan bahwa cekaman kekeringan yang diaplikasikan belum masuk periode kritis tanaman.

\section{SIMPULAN}

1. Varietas Cisadane merupakan varietas yang paling toleran terhadap cekaman kekeringan dibandingkan varietas lainnya.

2. Cekaman kekeringan yang terjadi pada periode vegetatif menurunkan hasil biji per rumpun.

\section{DAFTAR PUSTAKA}

Abdullah, B. 2002. Inovasi Teknologi Padi Tipe Baru, Pengelolaan Tanaman dan Sumberdaya Terpadu, dan Integrasi Padi dengan Ternak. Makalah disampaikan pada Temu Lapang BALITPA di KP Pusaka Negara, Subang 26 September 2002.

International Network for Genetic Evaluation of Rice and Internationa Rice Research Institute.1996. Standard Evaluation System For Rice. IRRI-International Rice Reseach Institute.

Badan Pusat Statistik. 2013. Banyaknya Desa atau Kelurahan Menurut Jenis Bencana Alam dalam Tiga Tahun Terakhir. https:/ /www.bps.go.id/index.php/linkTabelStatis/1726. Diakses pada 14 Maret 2014

Gardner, F.P, R. Brent Pearce dan Goger,L. M 1991. Fisiologi Tanaman Budidaya. Ul-Press. Jakarta. 428 hal

Pirdahsti, H., Zinolabedin T.S, Nematzadeh, G dan A. Ismail. 2004. Study of Water Stress Effects in DifferentGrowth Stages on Yield and Componen of Different Rice (oryza satival) Cultivar. Proceedings of the 4th International Crop Science Congress Brisbane. Australia .26-1. http// www.cropscience.org.au.

Suardi, D. 2002. Perakaran Padi dalam Hubungannya dengan Toleransi Tanaman terhadap Kekeringan dan Hasil. Jurnal Litbang pertanian. 21 (B0. 2002. http// biogen. Litbang. Deptan.

Suardi, D. 2000. Kajian Metode Skrining Padi Tahan Kekeringan. Jurnal Tinjauan Ilmiah Riset Biologi dan Bioteknologi Pertanian vol (3). 155-167

Soemartono, B. Samad, R. Hardjono. 1979. Bercocok Tanam Padi. Yasaguna. Jakarta. 